\title{
The Research on Issue and Countermeasures of Accounting
}

\section{Information of SMES}

\author{
Lijuan Zhou \\ School of Business, Tianjin Polytechnic University \\ Tianjin 300160, China \\ E-mail: zhoujuan125211@163.com
}

\begin{abstract}
The accounting information is accompanied by the rapid development of information technology; the development is the further deepening of computerized accounting. The large-scale enterprises put more emphasis on development of accounting information, while accounting for the majority of SMES in China because of many problems, there is no implementation of the accounting information or the results are poor, which for economic development of China is a significant impact, thus improving the level of accounting information of SEMS is very necessary. This paper describes in detail the problems faced by accounting information of SEMS and how to resolve these issues to make it a better service for SMES
\end{abstract}

Keywords: SMES, Accounting information, Accounting computerization

\section{An Overview of the Accounting Information}

As economic development of China and the continued improvement of science and technology, accounting computerization has obviously not meet people's requirements, but there are many problems. Complying with the development of the time, the accounting information has been into the accounting field. Based on the electronic computer accounting Information is the short of modern electronic technology and information technology applied to the accounting practices and It uses modern information technology, restructures the traditional accounting model and on the basis of the reorganization of modern accounting builds a modern accounting information system which is highly integrated and fully open in information technology and accounting disciplines. It is not just information technology applied to accounting change, but it is more representative of a modern information technology environment to adapt to the new accounting ideas.

Current accounting information is already very popular in China, the development is very rapid, and large-scale enterprises generally have achieved accounting information, and through surveys of SMES in China we find that the implementation of accounting information is not very optimistic, and because of various reasons, the majority of SMES unable to find a suitable way of accounting information, thereby affecting the speed of development of the entire national economic information.

\section{The Main Problems in the Process of Implementation of Accounting Information for SMES}

Accounting Information has made initial success after the development of 20 years in China, but limited to various aspects of the reasons there have arisen some problems in the process of development, specific features are as follows:

\subsection{The lack of software matched with the actual situation of SMES}

At present it is difficult to buy accounting information software matched with the actual situation of small and medium enterprises. The reasons are relatively significant:

\subsubsection{Developers cannot make the medium-sized software for SEMS}

In China, due to a very large number of SMES, their business volume, the business side are very wide, and each company has its own operating characteristics and mode of operation, which makes the IT service providers are very difficult to meet the needs of SMES although work hard, and makes it impossible for IT service providers to develop the software matched with the actual situation of SMES in-one correspondence.

\subsubsection{The development of software is not in place}

Since the accounting information is closely integrated between the accounting and information technology which requires developers who are proficient in accounting and information technology, but now the developer is often difficult to achieve this requirement. Some developers of financial software lack of accounting knowledge which makes 
software's features are not comprehensive, and some software developers have an only short-term training on only the content of basic accounting. Such software is difficult to meet needs of the business accounting information and internal control.

\subsection{The internal managers of the SMES have not adequate attention}

\subsubsection{The objective aspect}

For the small and medium enterprises, because of its small size, its poor strength, especially for the just started small businesses, the cash-strapped, the limited human resources, combined with the procurement, market development, and many other difficulties, make the managers of SMES have no time to take into account the implementation of accounting information.

\subsubsection{The subjective aspect}

As the main manager in enterprises, because of their lack of knowledge and vision, they do not know what is the accounting information or know of accounting information, but does not understand or recognize the advantages it brings, and think there is no need to introduce financial software to replace the manual accounting, largely reluctant to put too much cost on it. If introduce the advanced financial software, they must equip with professional staff, or spend money on staff training. They think these expenses are not much need for their business. Another factor for consideration could be the implementation of accounting information is not conducive to their escape the tax administration.

\subsection{SMES can not evaluate their conditions of accounting information correctly and objectively}

SEMS which are preparing for the implementation of accounting information have a widespread problem that they can not properly evaluate their own businesses before introduction of financial software to prepare for the implementation of accounting information, that is to say they have no clear understanding of the actual situation of this company, such as the level of management, the level of computer hardware and software, technical level, and so on, but they have chosen blindly a software in large number of financial software which is not suitable for the actual situation of the enterprise, In this way it not only will not bring benefits to the enterprise, it will add more non-essential costs.

\subsection{SMES lack of multi-talented}

Accounting Information Management is a very systematic and comprehensive work, if an enterprise prepare to implement accounting information, it needs the people who not only are able to master modern electronic technology, network technology, accounting, information technology, but also understand the company own operating characteristics and shortcomings. At present, overall quality of accounting personnel is still very low in our country. Accounting information for them was something new; they can not master the advanced management methods in time and can not quite understand the performance of the financial software, making the implementation of accounting information system hard. But SEMS especially the small businesses is difficult to attract talent, on the one hand because employers don't look the employment of private enterprises as a real job, worrying that the employment of private enterprises is vulnerable to social discrimination, on the other hand, companies are reluctant to spend more money to attracting the talent, and they contend the existing people and equipments have been ready to run the enterprise. These are contrary to accounting information technology required today, so an urgent need needs to be improved and enhanced.

\section{How to Accelerate the Pace of Accounting Information for SMES}

The many problems of small and medium enterprises are obvious; in order to solve these problems, and better implement accounting information in the small and medium enterprises, needing to do the following:

\subsection{Regulate the market and increase depth of software development for SMES}

In the design of financial software, the developers as far as possible take into account the characteristics of small and medium enterprises and the combination of enterprise development and the actual situation to make the function of financial software growing and a organic combination of financial accounting, financial management and modern information technology, and fully consider how to deal with personalized demand, master the degrees for demand control, analyze the impact these individual needs have brought to the fast realization of accounting information. And try to drive down the cost of application software, in order to make small and medium enterprises achieve the accounting information at the fastest speed. At the same time according to the needs of different period of enterprises' development, they should meet the needs of the software upgrades and re-development, help SMES train accounting people' operational capability, resolve all the problems arising in the use of the software and do after-sales service.

\subsection{Strengthen the responsibility of the administering authority}

Accounting information is a systematic project; the implementation is very difficult, so it needs corporate managers' great attention and they must organize, lead and supervise the process of implementation of accounting information. 
First of all, they must improve their quality and aware of the accounting information is an important part of business, Second, they should require employees to change their thinking and do in-house publicity and education to enable all workers of enterprises to recognize the need of the accounting information technology, under the circumstances of combination of modern information technology, which will greatly improve economic efficiency of enterprises. After the common understanding, they must give the necessary action and in the process of implementation of the project they need mutual cooperation and coordination among the various departments.

\subsection{Evaluate the accounting information conditions of enterprises objectively}

Preparations for the implementation of accounting information for small and medium enterprises, the most important thing is that form the objective circumstances of the enterprise, truly, accurately evaluate the enterprises' current conditions of the implementation of accounting information, analyze the types of enterprise and at present the level of corporate computer hardware and software, management level and the overall quality of the staff. After a full understanding on the enterprise, we can go to choose suitable financial software for our enterprise' development. If you choose financial software suitable for the enterprise's development, it will bring huge economic benefits and benefit the entire enterprise and there will be a great improvement for the level of the enterprise's management or the overall quality, of course, it forms a virtuous circle. However, if we don't analyze the actual situation of the enterprise well, blindly implement the accounting information, so that will not be able to bring benefit, on the contrary, it will bring great losses to there company because the implementation of software requires large investment costs, human and material resources.

\subsection{To increase the educational depth of accounting information}

Enterprise is a information system which is composed of people, goods, capital and information. People are decisive factor in the development of accounting information technology. High-quality accounting personnel are essential for achieving accounting information, so the state should adopt various forms to improve the quality of accounting information technology professionals.

\subsubsection{Strengthen the educational depth of software developers}

Increase the depth of modern information and accounting information technology and other professional in higher education to cultivate multi-talented rapidly to build a high-quality, high-tech team of software development.

\subsubsection{Strengthen training of managers of small and medium enterprises.}

In China we should establish gradually a talent pool of managers and enhance our country's overall level of business operations.

\subsubsection{Strengthen the training of SMES employees.}

The use of higher vocational education, vocational secondary schools and specialized secondary schools, technical schools and other training methods at different levels, the enterprises cultivate multi-level accounting information personnel for the SME to improve enterprises' quality.

\section{References}

Chi Bencai. (2006). Some thinks on enterprises continuing education. Continuing Education, (3), 52 - 53.

Chen, Shunquan. (2007). The problem in application of SMES accounting information. Mudanjiang College of Education, (5), 160-162.

Zeng, Tiegang. (2007). The problems and countermeasures in the process of accounting information. Heilongjiang Science and Technology Information, (6), 77-77.

$\mathrm{Gu}$, Wenrong. (2008). Problems and countermeasures on implementation of accounting information technology of our country small business. Accounting Research, (11), 44-45.

Wang, Yongqi. (2009). The principal problems and countermeasures of the current accounting information of. Business culture, (2), 49-50. 